\title{
ZASTOSOWANIE KESONÓW W POSADOWIENIU MORSKICH TURBIN WIATROWYCH. OPIS PROCESU INSTALACJI
}

\author{
Daniel Wrzosek ${ }^{凶}$ \\ independent researcher
}

\section{STRESZCZENIE}

Celem artykułu jest przybliżenie możliwości zastosowania kesonów przy budowie morskich farm wiatrowych. W pracy przedstawiono budowę i właściwości takich konstrukcji, obciążenia, proces instalacji i zagrożenia, z jakimi ich projektanci muszą się zmierzyć.

Słowa kluczowe: kesony morskie, turbiny wiatrowe, farmy, fundament

\section{WSTĘP}

W ostatnich latach nastąpił znaczny rozwój morskiej energetyki wiatrowej. Posadowienie morskich turbin wiatrowych różni się jednak od typowych konstrukcji morskich, w których zazwyczaj liczba fundamentów jest niewielka. Na farmach wiatrowych zachodzi potrzeba instalowania wielu fundamentów (na farmę wiatrową może przypadać od 20 do 250 turbin), dlatego poszukiwane są rozwiązania nie tylko zapewniające bezpieczeństwo konstrukcji, ale też korzystne ekonomicznie. Stabilność konstrukcji można uzyskać poprzez posadowienie stałe (monopale, fundamenty grawitacyjne, kesony zasysające, trójnogi, fundamenty kratownicowe) lub wypornościowe (platformy pontonowe, platformy kolumnowe, platformy cięgnowe tension leg platform - TLP). Coraz większą popularność w morskiej energetyce wiatrowej zyskuje rozwiązanie z zastosowaniem kesonów ssących. W porównaniu do innych fundamentów turbin wiatrowych wyróżniają się one między innymi takimi zaletami, jak: szybka instalacja i demontaż, przenoszenie dużych obciążeń poziomych i pionowych, a także brak drgań i hałasu podczas instalacji.

Poniższy artykuł przybliża właśnie ten typ posadowienia turbin wiatrowych.

\section{TYPOWE WYMIARY I BUDOWA TURBINY WIATROWEJ POSADOWIONEJ NA KESONACH}

Typowa turbina (rys. 1) zbudowana jest $\mathrm{z}$ wirnika o średnicy $80-100 \mathrm{~m}$ z piastą zlokalizowaną $80-90 \mathrm{~m}$ nad średnim poziomem morza. Ich rozmiary są jednak zróżnicowane, a wieże projektowanych turbin o mocy $12 \mathrm{MW}$ mogą osiągać nawet do $260 \mathrm{~m}$ wysokości. Gondola turbiny znajduje się na wieży stalowej lub betonowej. Odpowiedni element łączący pozwala na usytuowanie wieży na fundamencie.

Kesony mogą być instalowane zarówno na płytkich, jak i głębokich wodach. Zazwyczaj turbina wiatrowa jest posadowiona na pojedynczym kesonie (monopod), jednak dla wież o większych rozmiarach możliwe jest podparcie konstrukcji na trzech (tripod) lub czterech kesonach (tetrapod) (Houlsby, Ibsen i Byrne, 2005; rys. 2). W przypadku kilku 


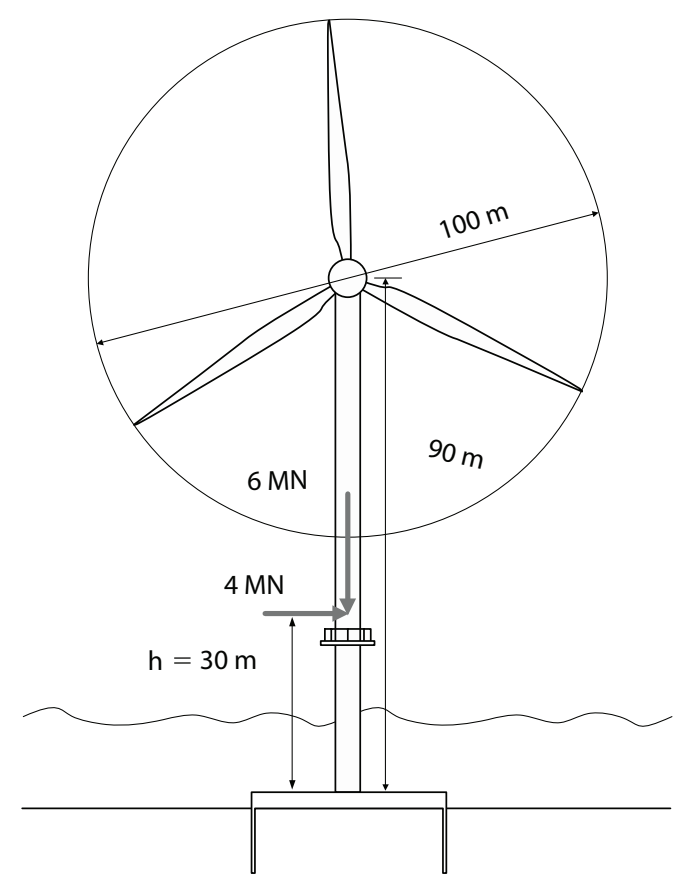

Rys. 1. Typowa turbina wiatrowa i obciążenia działające na nią (Houlsby, Ibsen i Byrne, 2005)

Fig. 1. Typical loads acting on an offshore wind turbine (Houlsby, Ibsen \& Byrne, 2005)

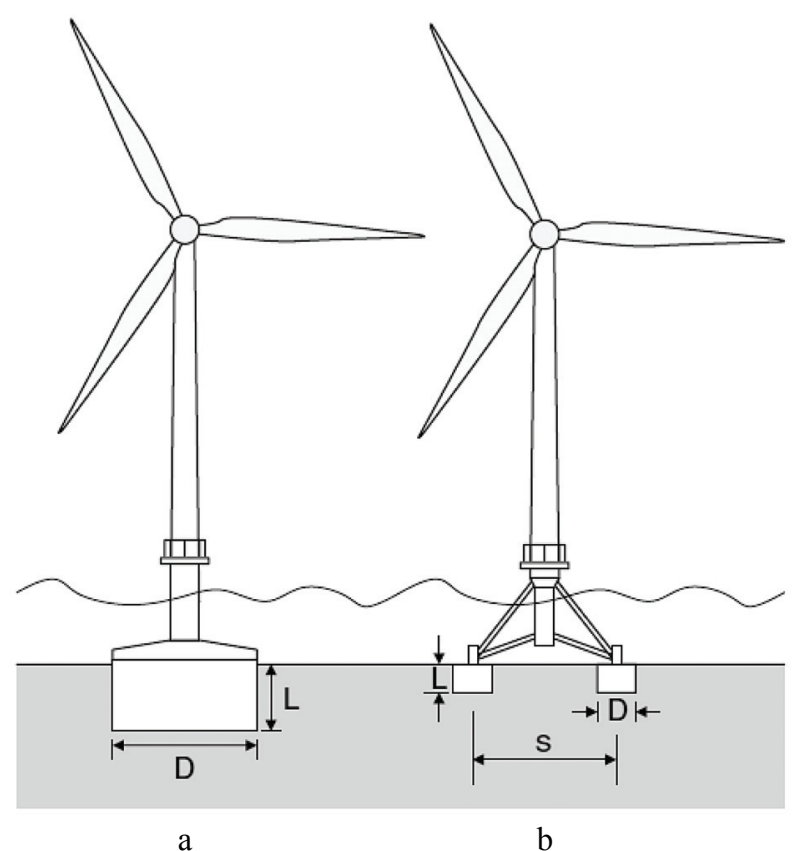

Rys. 2. Posadowienie turbin wiatrowych na kesonach: $a$ - monopod; b - tripod/tetrapod (Houlsby $i$ in. 2005)

Fig. 2. Caisson foundations for a wind turbine: $a$ - monopod; $b$ - tripod/tetrapod (Houlsby et al., 2005) 
podpór moment obracający obciąża przeciwnie kilka współpracujących kesonów (podczas obciążenia konstrukcji jedne są wyciągane, drugie dociskane do gruntu w zależności od kierunku działania obciążenia poziomego).

\section{BUDOWA I ZASADA DZIAŁANIA KESONU}

Keson jest stalową lub żelbetową konstrukcją w kształcie walcowego zbiornika $\mathrm{z}$ otwartym dnem, zagłębianą w podłożu. Składa się z pokrywy i płaszcza bocznego. Na jego pokrywie znajdują się zawory umożliwiające odprowadzenie lub doprowadzenie wody i powietrza do wnętrza kesonu.

Rysunek 3 przedstawia przekrój typowego kesonu. Keson może dodatkowo mieć usztywnienia zapobiegające wyboczeniu ścian płaszcza podczas montażu. Stosunek długości płaszcza do średnicy pokrywy zazwyczaj wynosi ok. $4\left(L / D_{o} \approx 4\right)$, lecz może różnić się $\mathrm{w}$ zależności od gruntów, w jakich jest posadowiony. Można przyjąć, że stosunek długości płaszcza do średnicy zewnętrznej wynosi dla piasków $L / D_{o}<1$, a dla gruntów spoistych $L / D_{o}=3 \div 9$ (Wachowski, 2016).

W przypadku posadowienia turbin wiatrowych istota jego działania jest inna niż dla kesonu tradycyjnego. Keson ssący oprócz przenoszenia obciążeń poziomych pracuje na wciskanie i wyciąganie. Przy obciążeniach wciskających (np. od konstrukcji turbiny posadowionej na nim) keson pracuje jak klasyczny fundament lub pal, a w przypadku sił wyciągających odrywaniu kesonu od dna morskiego zapobiega podciśnienie występujące na wewnętrznej powierzchni pokrywy (ssanie pasywne), tarcie gruntu na pobocznicy oraz ciężar własny z ewentualnym balastem (Cao, Philips, Popescu, Al-Khafaji i Audibert, 2002).

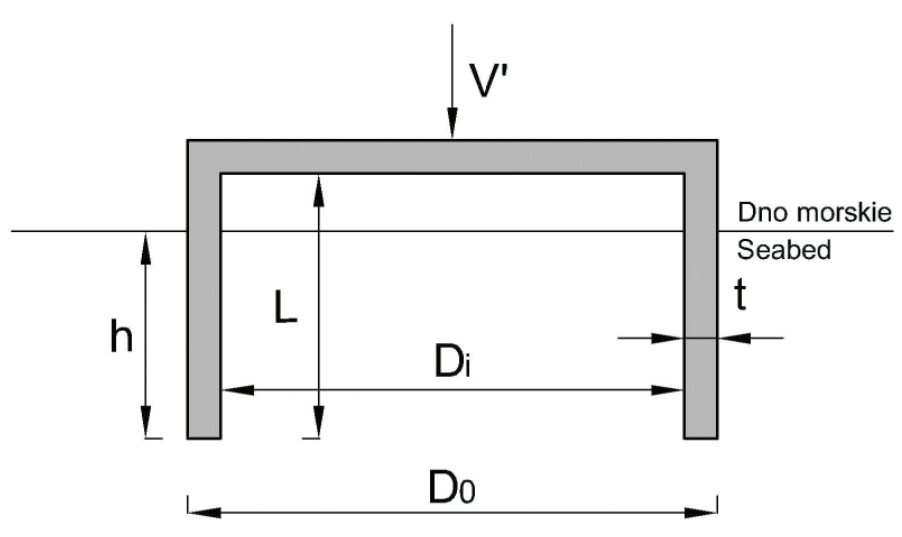

Rys. 3. Przekrój kesonu: $D_{o}-$ średnica zewnętrzna; $D_{i}-$ średnica wewnętrzna; $t$ - grubość płaszcza; $L$ - długość płaszcza; $h$ - zagłębienie płaszcza (Houlsby i in., 2005)

Fig. 3. Geometry of a caisson foundation: $D_{o}-$ outside diameter; $D_{i}-$ inside diameter; $t$ - skirt wall thickness; $L$ - skirt length; $h$ - skirt foundation depth (Houlsby et al., 2005)

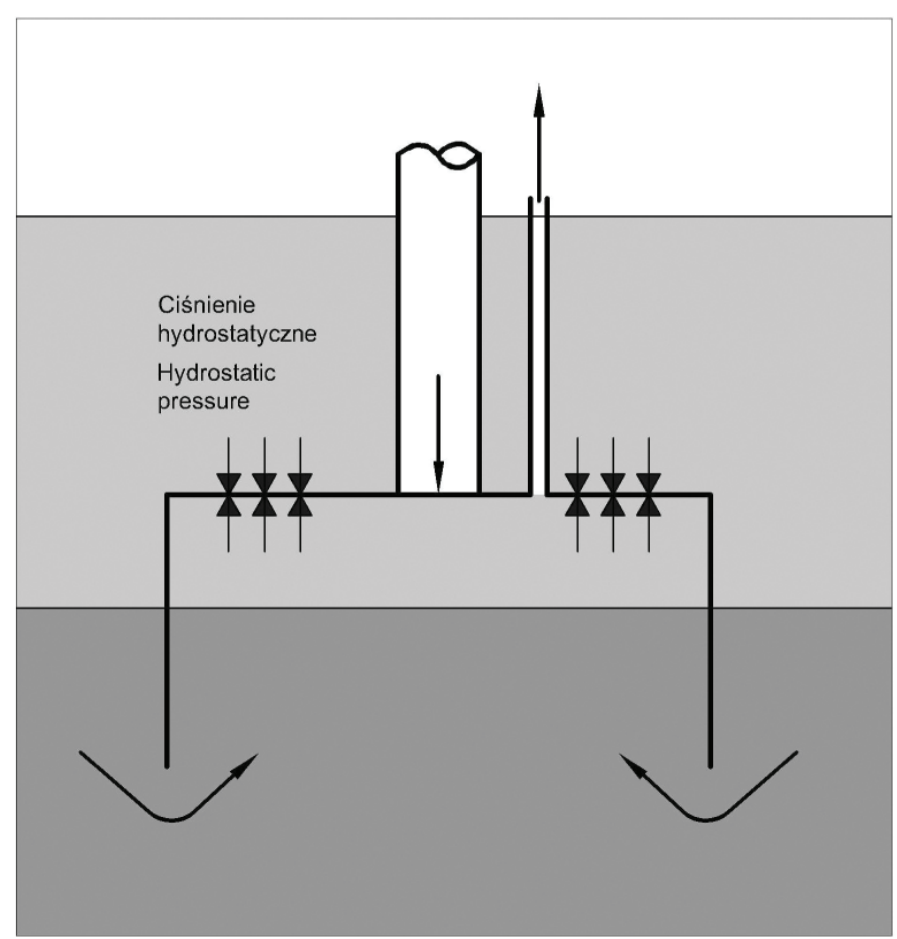

Rys.4. Schemat działania kesonu zasysającego (Tarerłko, 2015)

Fig. 4. Suction caisson work mechanism (Tarerłko, 2015) 


\section{PRZEPROWADZANE BADANIA}

Zarówno na pojedynczych kesonach, jak i na obu konfiguracjach (tripod, tetrapod) przeprowadzano badania modelowe (Houlsby i in., 2005).

W przypadku pojedynczych kesonów rozległe badania przeprowadzone zostały przez Uniwersytet w Aalborg (Houlsby i in., 2005) przy współpracy z MDB Offshore Power. Zastosowano modele w dużej skali, wspomagane badaniami laboratoryjnymi. Przebadano w nich wiele kombinacji obciążeń, a testy polegały na obciążaniu siłą poziomą na pewnej wysokości, przy stałym obciążeniu pionowym. Każdy przypadek testowy składał się z fazy instalacji, eksploatacji i demontażu. Przebadano obciążenia modelujące warunki dla różnych głębokości posadowienia (Houlsby i in., 2005). Innym typem badań prowadzonych na kesonach jest wyciąganie modeli kesonów ssących przeprowadzone w szklanym zbiorniku dla różnych prędkości wyciagania dla gruntów spoistych oraz niespoistych, mające na celu zbadanie uniesienia korka we wnętrzu kesonu (Kelly, Byrne, Houlsby i Martin, 2003).

Wyniki przeprowadzonych badań pozwoliły na rozpoznanie zjawisk zachodzących w kesonach podczas ich instalacji i wyciągania dla różnych warunków gruntowych. W gruntach spoistych spowodowane wypompowywaniem wody z wnętrza kesonu podciśnienie powoduje przy uprzednim dokładnym zbadaniu dna przeważnie bezproblemowe zagłębianie się fundamentu $\mathrm{w}$ gruncie. W przypadku instalacji w gruntach niespoistych podciśnienie powoduje dodatkowy przepływ wody w gruncie przy podstawie konstrukcji i jej pobocznicy. Znaczna różnica ciśnień wewnątrz i na zewnątrz kesonu, niezbędna do odpowiedniego zagłębienia kesonu w dnie piaszczystym, może doprowadzić do awarii konstrukcji fundamentu poprzez wyboczenie ścian jego płaszcza. Podczas deinstalacji fundamentu również odnotowuje się występowanie większych sił wyciągających w gruntach niespoistych niż $\mathrm{w}$ gruntach spoistych. Z tego powodu konstrukcje kesonów ssących przewidziane do posadowienia w gruntach niespoistych muszą być bardziej masywne i wytrzymałe (Wachowski, 2016).

Wspomniane konfiguracje (tripod, tetrapod) przetestowano dla przypadków podłoża jednorodnego zarówno w piaskach, jak i glinach. $\mathrm{W}$ piaskach odbyło się to poprzez osiowe obciążanie kesonów z różną siłą (Houlsby i in., 2005) oraz ich cykliczne osiowe obciążanie. Obydwa badania miały na celu zbadanie przemieszczeń pionowych. Podczas badań obserwowano i analizowano pojawianie się naprężeń w płaszczu kesonów. Badania wykazały niewielką nośność w trakcie pogrążania ścian, która jednak znacznie wzrasta, gdy pokrywa zaczyna mieć kontakt z gruntem. Cykliczne obciążanie wykazało osłabianie tarcia na płaszczu, widoczne poprzez wzrost zarejestrowanych przemieszczeń, po przekroczeniu granicznej wartości tarcia na jego powierzchni. Dla przypadku podłoża gliniastego wykonano stosunkowo niewiele badań. Te, które przeprowadzono (Houlsby i in., 2005), polegały na osiowym obciążaniu i wskazały na większą sztywność konstrukcji obciążanych bezpośrednio po instalacji w stosunku do tych, które już wcześniej były poddawane obciążaniom.

$\mathrm{Na}$ podstawie badań Houlsby'ego i in. (2005) ustalono, że spośród rozpatrywanych konfiguracji (tripod, tetrapod) zastosowanie czterech kesonów jest nieznacznie korzystniejsze. Wyliczono, że przy zastosowaniu tetrapodu naprężenia w konstrukcji są mniejsze niż w przypadku tripodu. Dodatkowo, pomimo że składa się on z czterech, a nie trzech kesonów, całkowita suma ciężarów użytych materiałów jest mniejsza (Houlsby i in., 2005).

\section{PROJEKTOWANIE KESONU}

W projektowaniu kesonów należy rozpatrzyć dwie fazy (instalacji i pracy), w których to konstrukcja podlega odmiennym obciążeniom.

\section{Faza instalacji}

W fazie instalacji keson jest opuszczony ze statku na dno morskie (rys. 5 - etap 1). Zawory umieszczone na jego pokrywie są otwarte, dzięki czemu powietrze może swobodnie wypływać z jego wnętrza. Początkowo zagłębia się on pod wpływem własnego ciężaru, dopóki opór gruntu nie zatrzyma dalszej penetracji konstrukcji (rys. 5 - etap 2). W tym momencie zawory są zakręcane i następuje wypompowywanie wody $\mathrm{z}$ wnętrza kesonu pompami umieszczonych np. na statku (ssanie aktywne). Usuwanie wody $\mathrm{z}$ wnętrza fundamentu pozwala uzyskać różnicę ciśnień między 


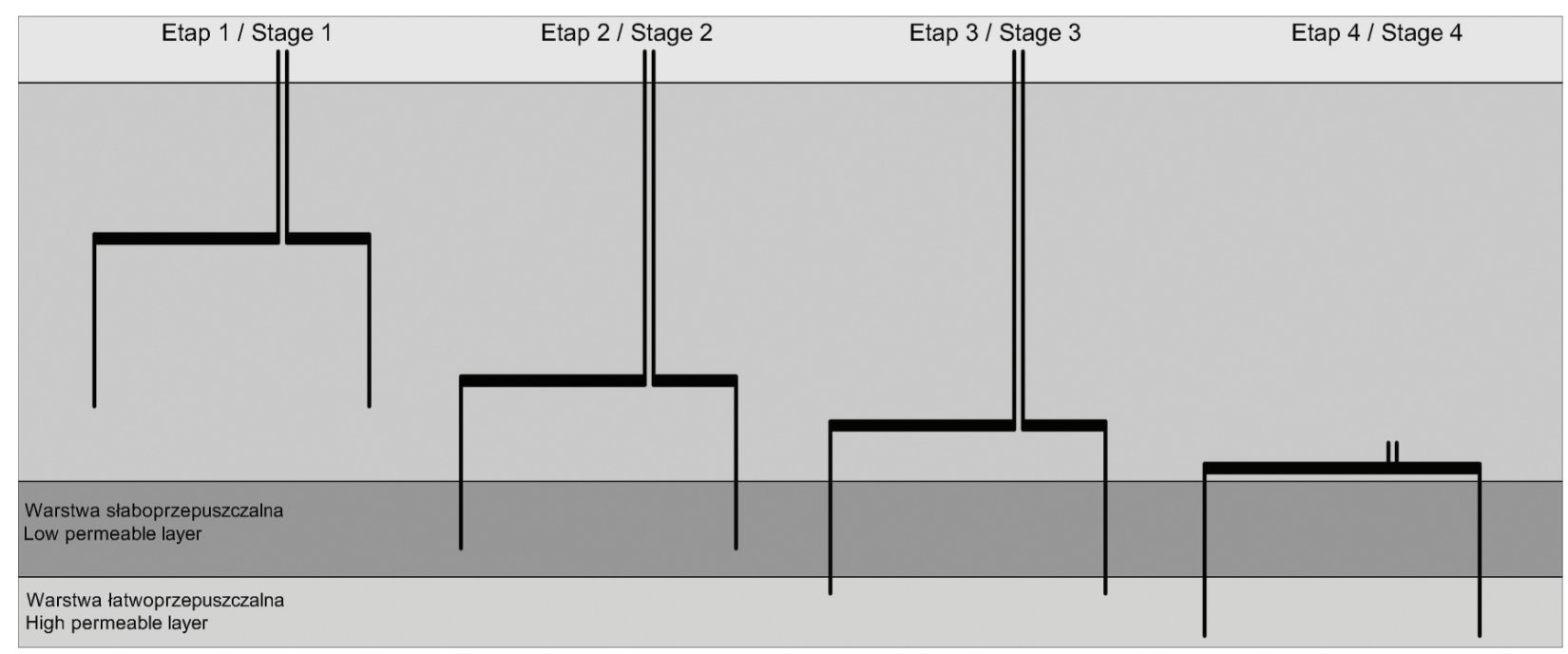

Rys. 5. Faza instalacji kesonu (opracowanie własne na podstawie Sahroni, 2015)

Fig. 5. Suction caisson installation (own elaboration on the basis of Sahroni, 2015

wewnętrzną a zewnętrzną częścią pokrywy kesonu, co powoduje dalsze zagłębianie się fundamentu.

Można założyć, że opory w gruncie w trakcie penetracji kesonu odpowiadają tym, jakie napotykają osiowo obciążone pale otwarte. Dla warunków bez odpływu opory, jakie napotyka zagłębiający się keson, można wyliczyć jako sumę tarcia na powierzchni zewnętrznej i wewnętrznej płaszcza i oporu na jego ostrzu. W przypadku warunków z odpływem sytuacja wygląda inaczej. Przez ciśnienie wywołane działaniem pompy znajdującej się na statku w gruncie dochodzi do filtracji od zewnętrz do wnętrza kesonu. Pionowy przepływ wody w gruncie występujący wewnątrz kesonu powoduje obniżenie efektywnych naprężeń pionowych, w związku z czym zmniejsza się wewnętrzne tarcie na ścianach płaszcza. Przepływ wody obniża także opory w miejscu ostrza płaszcza. Przyłożone ciśnienie ssące ma zatem podwójną rolę w przypadku z odpływem: zwiększa siłę zagłębiania konstrukcji i zmniejsza opory w gruntach przepuszczalnych (Sturm, 2017).

Należy również zwrócić uwagę na możliwość utraty stateczności hydraulicznej, do której może dojść przez pojawienie się filtracji, sufozji i formowanie się kanałów rozluźnionego gruntu, oraz w ostateczności przebicia hydraulicznego.

Pompowanie ustaje $\mathrm{w}$ momencie osiągnięcia przez fundament projektowanego zagłębienia $\mathrm{w}$ dnie morskim (rys. 5 - etap 3). Zagłębiony keson jest gotowy na przyjęcie obciążeń pochodzących od konstrukcji oraz obciążeń środowiskowych (rys. 5 - etap 4).

Uzyskane w procesie instalacji podciśnienie wewnątrz kesonu (ssanie aktywne) działa tylko podczas instalacji i krótko po - aż ulegnie rozproszeniu. Podczas wyciągania kesonu na wewnętrznej stronie jego pokrywy powstaje ssanie pasywne, które zwiększa nośność tego fundamentu na wyciąganie.

Keson może być także łatwo zdemontowany poprzez odwrócenie procesu instalacji, dzięki czemu można go stosować wielokrotnie lub odholować w celach remontowych, jeśli uległ uszkodzeniu. Po otworzeniu zaworów ciśnienie wewnątrz i na zewnątrz kesonu się wyrównuje, a konstrukcja może być podniesiona za pomocą wyciągarki. W razie problemów można wtłoczyć do środka kesonu wodę lub powietrze, co ułatwia cały proces (Wachowski, 2016).

\section{Faza pracy}

Po zainstalowaniu keson działa podobnie jak krótki wielkośrednicowy pal o dużej sztywności zdolny do przenoszenia zarówno pionowych, jak i poziomych obciążeń.

Fundamenty turbin wiatrowych poddawane są nietypowym obciążeniom. Siły działające w kie- 
runku poziomym i momenty są tu dużo większe niż w przypadku typowych konstrukcji. Siły poziome mogą osiągać tu do $60 \%$ wartości sił pionowych.

Turbina jest obciążona przez wiatr, falowanie, prądy morskie i ciężar własny. Wartości obciążeń można przyjąć dla przeciętnej turbiny jak na rysunku 1 . Obciążenie pochodzące od falowania znacznie przewyższa obciążenie wiatrem, ale ponieważ obciążenie wiatrem jest przyłożone w wyższym punkcie, wywołuje ono większy moment obracający, który zazwyczaj jest kluczową składową obciążeń.

Nośność takiego fundamentu może różnić się w zależności od ciężaru gruntu objętego przez zagłębiony płaszcz kesonu. Stateczność konstrukcji jest zapewniona, ponieważ ssanie pasywne zapobiega wynurzeniu kesonu $\mathrm{z}$ dna morza podczas jednego okresu działania fali (Tarełko, 2015).

\section{KESONY - ZAGROŻENIA}

Podczas projektowania kesonów należy uwzględnić trudności, na jakie można natrafić w fazie zarówno instalacji, jak i pracy (rys. 6).

\section{Badania podłoża}

Przed fazą instalacji należy dokładnie zbadać dno morskie, aby uniknąć zagrożeń dla konstrukcji, takich jak:

- nierówne dno morskie (rys. 6f),

- obecność głazów, przeszkód i niewielkich kraterów (rys. 6h),

- uskoki terenu,

- erozja osadów dennych wskutek działania mas lodu,

- podmorska wieczna zmarzlina lub grunty powiązane lodem.

Badania gruntu pomocne są także w uniknięciu problemów podczas zagłębiania kesonu, np. zablokowania penetracji (rys. 6d) i przechylenia konstrukcji (rys. 6g)

\section{Faza instalacji}

W fazie instalacji należy uwzględnić podciśnienie krytyczne (ang. critical underpressure), które może powstać wewnątrz kesonu. Jeśli podciśnienie krytyczne zostanie przekroczone, dalsze zagłębianie może nie być możliwe.
W gruntach niespoistych w wyniku przekroczenia ciśnienia krytycznego cząstki gruntu przemieszczają się wraz z przepływającą wodą i mamy do czynienia $\mathrm{z}$ rozluźnieniem gruntu wewnątrz kesonu (rys. 6c).

W gruntach spoistych może nastąpić przebicie hydrauliczne wzdłuż ścianek lub w masie gruntu tworzącego korek gruntowy. Możliwe jest odspojenie warstwy słabo przepuszczalnej od warstwy gruntu piaszczystego.

Maksymalne zalecane zagłębienie płaszcza to takie, dla którego podciśnienie krytyczne jest osiągnięte ze współczynnikiem bezpieczeństwa 1,5.

Ciśnienie stosowane w pompie wywołującej ssanie aktywne nie powinno przekraczać ciśnienia kawitacyjnego, które opisane jest następująco:

$$
p_{c a v, \text { max }}=\left(z+w_{s}\right) \gamma_{w}^{\prime}+p_{a t m}
$$

gdzie:

$z \quad$ - głębokość poniżej dna morskiego [m],

$w_{s}$ - głębokość wody, poniżej której przyłożone jest ciśnienie [m],

$\gamma_{w}^{\prime}-$ ciężar objętościowy wody, $\gamma_{w}=10\left[\mathrm{kN} \cdot \mathrm{m}^{-2}\right]$,

$p_{a t m}-$ ciśnienie atmosferyczne, $p_{a t m}=100[\mathrm{kPa}]$.

Zatem wartość ciśnienia zależy od położenia pompy, która może znajdować się nie tylko na statku, ale też na powierzchni pokrywy lub dna.

Zróżnicowana budowa geologiczna podłoża dodatkowo komplikuje zagłębianie kesonu. Można wyróżnić dwa przypadki:

- warstwa piasku ponad warstwą gliny (przepuszczalna nad słabo przepuszczalną), powszechnie występująca na Bałtyku i Morzu Północnym,

- warstwa gliny ponad warstwą piasku (słabo przepuszczalna nad przepuszczalną).

Przeprowadzone testy laboratoryjne wskazywały, że penetracja w przypadku gdy piasek znajduje się poniżej warstwy gliny może nie być możliwa bez wzbudzania zjawiska unoszenia korka (rys. 6a). Zaleca się w takim przypadku przerwanie instalacji ponad warstwą piasku (Sturm, 2017). Praktyka nie do końca to potwierdza. Udowodniono, że jest możliwy montaż w tak uwarstwionym gruncie bez widocznego uniesienia korka, pod warunkiem że nastąpi on względnie szybko.

W fazie instalacji szczególnie narażonym elementem konstrukcji jest płaszcz, który może ulec wyboczeniu (rys. 6i). Niedoskonałości i zwichrzenie w okolicach 
Wrzosek, D. (2020). Zastosowanie kesonów w posadowieniu morskich turbin wiatrowych. Opis procesu instalacji. Acta Sci. Pol. Architectura, 19 (3), 75-82. doi: 10.22630/ASPA.2020.19.3.29

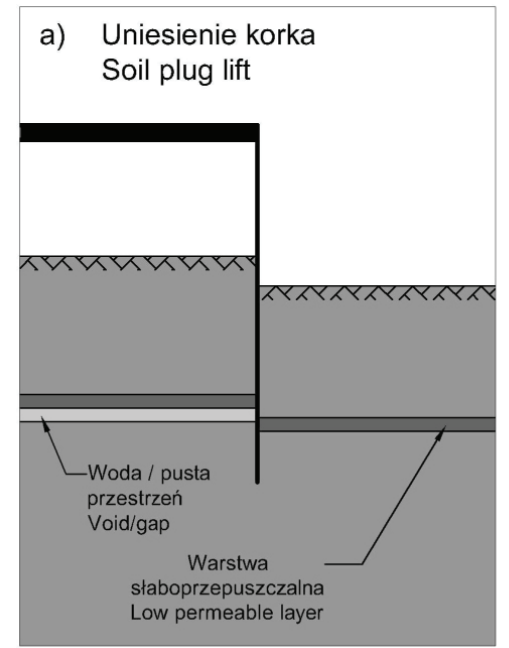

d) Blokowanie dalszej penetracji Stucking

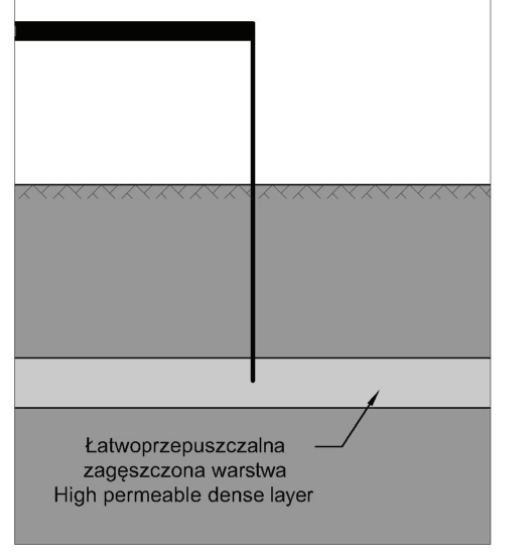

g) Przechylenie

Tilt

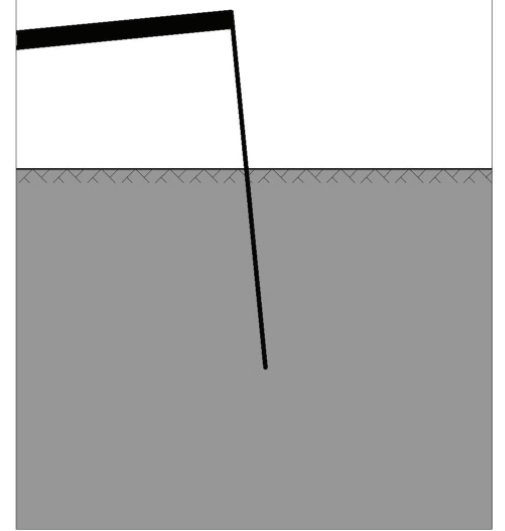

b) Formowanie kanałów przepływu Piping

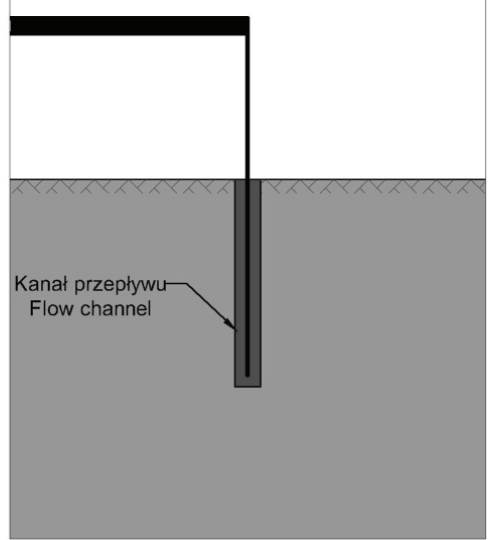

e) Nierówne dno morskie Uneven seabed

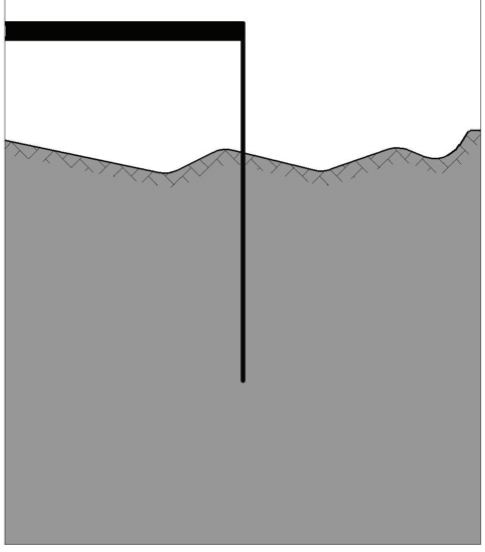

h) Obecność głazów Boulders

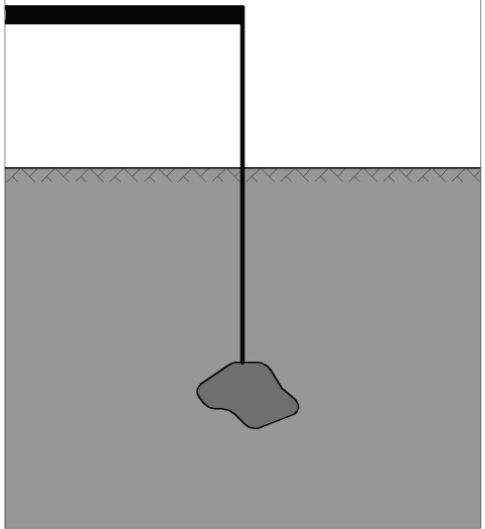

c) Rozluźnienie gruntu Excessive losening

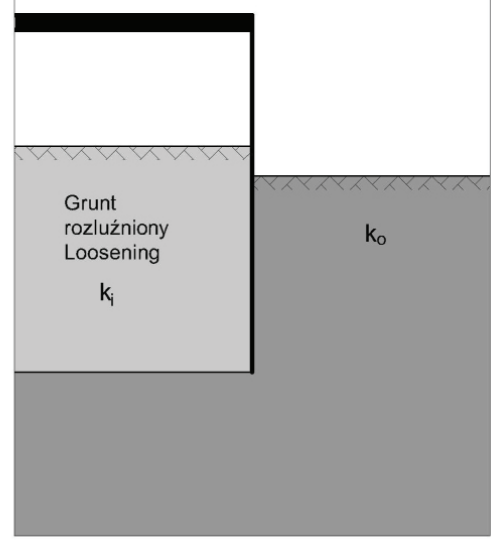

\section{f) Erozja wewnętrzna} Inner erosion

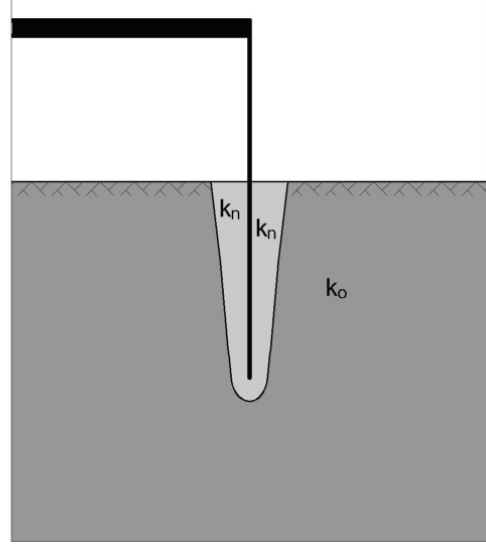

i) Wyboczenie ścian płaszcza Skirt buckling

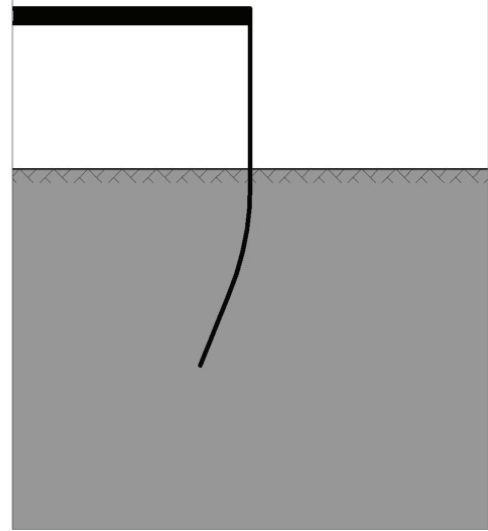

Rys. 6. Zagrożenia w trakcie instalacji kesonu (opracowanie własne na podstawie Sturm, 2017)

Fig. 6. Possible failure during installation (own elaboration on the basis of Sturm, 2017) 
ostrza płaszcza mogą znacząco zwiększyć opór gruntu podczas zagłębiania i działać negatywnie na zachowanie kesonu w fazie pracy. $Z$ tego powodu nieprzekraczanie ciśnienia krytycznego podczas odsysania powietrza z wnętrza kesonu jest tak istotne (Sturm, 2017).

\section{Faza pracy}

Kesony różnią się od tradycyjnych konstrukcji cyklicznym charakterem obciążeń. Wpływa on zarówno na konstrukcję (należy projektować ją na zmęczenie), jak i grunt, na którym jest posadowiona. Możliwe skutki obciążenia cyklicznego to:

- zmiany charakterystyk obciążenie-przemieszczenie, potencjału upłynnienia i stateczności zbocza pod wpływem dużej liczby cykli obciążeń;

- erozja (rys. 6f): w miejscach, gdzie jest spodziewana, należy zapewnić ochronę wkrótce po zainstalowaniu kesonu;

- formowanie kanałów przepływu w gruncie wzdłuż pionowego płaszcza lub szczelin - przebicie hydrauliczne (rys. 6b);

- utrata stateczności hydraulicznej przez osłabienie gruntu spowodowane ciśnieniem spływowym, siły filtracyjne, powstanie zjawiska przebicia hydraulicznego z towarzyszącą mu sufozją.

\section{PODSUMOWANIE}

Ze względu na swoje liczne zalety kesony stanowią interesującą alternatywę stosowanych obecnie rodzajów posadowień morskich turbin wiatrowych. Liczne wyzwania towarzyszace ich projektowaniu i zagrożenia mogące wystąpić $\mathrm{w}$ trakcie instalacji skłaniają do dalszych badań nad tym typem fundamentu, w szczególności nad posadowieniem w gruntach spoistych. Posiadanie pełnej wiedzy na temat zjawisk zachodzących podczas instalacji i pracy w różnych warunkach gruntowych jest niezbędne dla pełnego wykorzystania potencjału kesonów w posadowieniu turbin wiatrowych.

\section{PIŚMIENNICTWO}

Cao, J., Philips, R., Popescu, R., Al-Khafaji, Z. i Audibert, J. M. E. (2002). Penetration Resistance of Suction Caissons in Clay. W The Twelfth International Offshore and Polar Engineering Conference, Kitakyushu, 26-31.05.2002 (strony 800-806). The International Society of Offshore and Polar Engineers.

Houlsby, G. T., Ibsen, L. B. i Byrne, B. W. (2005). Suction caissons for wind turbines. W S. Gouvernec i M. Cassidy (red.), Frontiers in Offshore Geotechnics (IS-FOG 2005): Proceedings of the First International Symposium on Offshore Geotechnics, Perth, 19-21.09.2005 (strony 75-93). London: Taylor \& Francis Group.

Kelly, R. B., Byrne, B. W., Houlsby, G. T. i Martin, C. M. (2003). Pressure Chamber Testing of Model Caisson Foundations in Sand. W Proceedings of the International Conference on Foundations, Dundee, 02-05.09.2003 (strony 421-431). London: Thomas Telford.

Sahroni, T. R. (2015). Modeling and Simulation of Offshore Wind Power Platform for 5 MW Baseline NREL Turbine. The Scientific World Journal, 819384, doi: $10.1155 / 2015 / 819384$

Sturm, H. (2017). Design Aspects of Suction Caissons for Offshore Wind Turbine Foundations. W Y. Shin (red.), SSMGE Technical Commitee TC209 Offshore Geotechnics. 2017. Foundation Design of Offshore Wind Structures. Proceedings of TC 209 workshop 19th ICSMGE, Seul, 20.09.2017 (strony 45-63).

Tarełko, W. (2015). Morskie farmy wiatrowe: Posadowienie turbin wiatrowych. Inżynieria Morska i Geotechnika, 6, 889-897.

Wachowski, Ł. (2016). Kesony ssące - konstrukcja, instalacja, nośność. Inżynieria Morska i Geotechnika, 6, 339-344.

\title{
APPLICATION OF SUCTION CAISSONS AS FOUNDATIONS OF OFFSHORE POWER PLANTS. INSTALLATION PROCESS DESCRIPTION
}

\begin{abstract}
The purpose of the article is to present suction caissons as wind turbines foundations. Text presents construction, its properties, loads, installation process and problems encountered by its designers.
\end{abstract}

Key words: offshore caisson, wind turbines, farm, foundation 